International Research Journal of Management, IT \& Social Sciences
Available online at https://sloap.org/journals/index.php/irjmis/
Vol. 6 No. 5, September 2019, pages: 184 192
ISSN: 2395-7492
https://doi.org/10.21744/irjmis.v6n5.724

\title{
Predicting Business Performance Through Leadership Style and Job Motivation
}

Ida Bagus Semara Mantera P. ${ }^{\text {a }}$

I Gede Riana ${ }^{b}$

\section{Article history:}

Received: 27 March 2019

Accepted: 31 July 2019

Published: 01 September 2019

\section{Keywords:}

business;

job motivation;

leadership;

performance;

style;

\begin{abstract}
Leadership is a character, habit, and personality that distinguishes a person in interacting with others. Leadership is also considered a norm of behavior that is used when trying to influence the behavior of others. Leadership is not always associated with behavior in the right situation, but also how other people are involved so they want to think about realizing the organization's vision and mission. This study aims to analyze the influence of leadership style on Village Credit Institution (LPD) motivation and performance. The study used a questionnaire distributed to 115 employee respondents in 32 LPD in the city of Denpasar. The results of distributing questionnaires received 100 completed questionnaires and were declared valid. Furthermore, the data collected has been analyzed using descriptive analysis and inferential analysis using Smart PLS. The analysis showed that the leadership style had a significant effect on job motivation and LPD performance. Job motivation has a significant effect on LPD performance. While the indirect influence of leadership style on LPD performance shows the important role of job motivation in improving LPD performance.
\end{abstract}

2395-7492@ Copyright 2019. The Author. This is an open-access article under the CC BY-SA license (https://creativecommons.org/licenses/by-sa/4.0/) All rights reserved.

\section{Author correspondence:}

Ida Bagus Semara Mantera P.,

Faculty of Economics and Business, Udayana University, Denpasar, Indonesia.

Email address: ghostman888@gmail.com

\section{Introduction}

One of the Microfinance Institutions (MFIs) that has developed in Bali is the Village Credit Institution (LPD). LPD is a microfinance institution owned by a customary village and is the only microfinance institution managed by an adat in Indonesia and even in the world. Until 2018 there were 1,433 LPD (LPLPDP Bali, 2018), spread across nine regencies/cities in Bali. Of these, Denpasar City has 35 LPD according to the number of existing customary villages (LPLPDK Denpasar, 2011). The results of investigative studies show that there are problems with LPD performance. This is generally seen from the low return on assets (ROA) achieved. Another LPD performance problem is the high

${ }^{a}$ Udayana University, Denpasar, Indonesia

${ }^{\mathrm{b}}$ Udayana University, Denpasar, Indonesia 
ratio of operating costs to operating income (BOPO), which has the potential to cause LPDs to become unhealthy. Some of these LPD performance problems have the potential to bring LPDs to face business performance problems, even leading to the non-operation of the LPD. This condition requires management to manage LPD better.

The results of the study stated that the leadership style had a significant effect on job motivation (Ali \& Meshal, 2016) and performance (Paracha et al., 2012; Martini et al., 2018). A number of studies have also suggested a significant influence between leadership style and organizational performance (Borrill et al., 2005; Waldman et al., 2005; Riana, 2015; Ogbonna \& Lioyd, 2000). While Rivai, (2014), states that the needs of employees need to be considered so that employees feel they receive fair treatment. Organizations need to provide job motivation so that employees carry out work better. Motivation is a series of forms of treatment given by management to encourage employees to do activities in achieving goals. Therefore motivation is needed to spur organizational performance in accordance with expectations (Ivancevich et al., 2005). The process of emergence of job motivation is a combination of the concepts of needs, encouragement, goals, and rewards (Robbins \& Judge, 2017). The study of the role of motivation in improving organizational performance is supported by research (Dobre, 2013; Nduka, 2016), that job motivation plays an important role in improving organizational performance.

According to Cole \& Shastry (2009), motivation is basically about what energizes a person to work in a particular method with a certain determination. Motivation is a predisposition to appear in achieving certain wants and needs (Buford et al., 1995), besides that motivation can also increase job satisfaction (Ryan \& Deci, 2000; Heyrani \& HamehKhani, 2017). Tylana (2006), states that job motivation can trigger job satisfaction which in turn affects performance. Eskildsen et al., (2003), tried to give an argument about motivation and its effect on performance. This study aims to analyze differences in performance due to motivation. The results of his research concluded several things such as (1) employees who have higher levels of education are more motivated than employees with lower levels of education, (2) managers prefer to provide intrinsic motivation for their work, while employees are accustomed to providing intrinsic motivation, and (3) employees with a younger age tend to have higher motivation.

\section{Literature Review}

A leader is someone who due to personal skills with or without an official appointment can effect a group that is led to direct joint efforts towards the achievement of certain goals (Robbins \& Judge, 2017). According to Luthans (2006), leaders as part of a group process, personality, fulfillment of certain behaviors, persuasion, strength, goals, achievement, role differentiation, initiation of structure, as well as a combination of two or more of these. Whereas Bernardin \& Russel (2005), stated that effective leaders, in general, are able to provide motivation for employees to work better. Job motivation represents a psychological process (Mitchell, 1992: Riana, 2015), that causes arising, directed, and the persistence of voluntary activities towards certain goals. Another formulation of motivation was stated by Robbins \& Judge (2017), that motivation is a willingness to carry out high efforts in achieving organizational goals which are conditioned by the ability to meet individual needs (Ivancevich et al., 2007; Mardika, 2017).

According to Yukl (2010), leadership style plays an important role in achieving organizational goals in the form of achievement or performance. Fiedler (1995), states that a leader who emphasizes the task structure, relationship structure, and position of power can have a positive impact on organizational performance. In line with this opinion Ivancevich et al., (2007), explained that leadership can affect an organization's performance. The influence of leadership style on organizational performance is carried out (Borrill et al., 2005; Waldman et al., 2005; Ogbonna \& Lioyd, 2000), concluding that there is a significant influence between leadership style on organizational performance.

Based on the description, the hypothesis proposed is as follows.

Hypothesis 1: Leadership style has a significant effect on LPD performance

Robbins \& Judge (2017), state that job motivation involves the outcome of interactions between individuals with the situation at hand. Further said at least there are 3 (three) things that are included in motivation, namely: individual intensity, continuity, and accuracy in achieving goals. Motivation is a condition and energy that moves a person to be more focused in achieving organizational goals (Slocum \& Hellriegel, 2011; Hidayat \& Budiatma, 2018). A positive mental attitude of a leader towards work situations can strengthen employee job motivation to achieve maximum performance (Fickie, 2007; Sari \& Dwirandra, 2019).

Research that has tested the truth of Herzberg's theory was carried out by Kabacoff (2002). Shows that there is a high degree of compatibility between personal motivation (working hard to get emotional results) and leadership style (specific leadership behavior). A number of research results show that leadership style has a significant effect on job motivation (Siregar et al., 2016; Ali \& Meshal, 2016; Runi et al., 2017). Leaders who are able to understand the

Mantera P., I. B. S., \& Riana, I. G. (2019). Predicting business performance through leadership style and job motivation. International Research Journal of Management, IT and Social Sciences, 6(5), 184-192. https://doi.org/10.21744/irjmis.v6n5.724 
subordinate's task structure well, can understand and appreciate the results of subordinate performance, and have a sense of psychological closeness with subordinates tend to be able to increase employee job motivation (Hanafiah $e t$ al., 2014).

Based on the description, the hypothesis proposed is as follows.

Hypothesis 2: Leadership style has a significant effect on job motivation

Li (1999), explains the relationship of job motivation and organizational performance by making fair rewards a motivational component that can affect performance levels. The results of the study (Herpen 2005; Tylana, 2006), concluded that job motivation influences performance. Someone involved in the organization has a number of expectations to be fulfilled so that in carrying out the work there is a match between expectations and reality, job satisfaction will arise while increasing performance. Based on these linkages, job motivation can have a positive influence because it affects a person in carrying out tasks and activities.

Gibson et al., (1996); Gani, (2006); and Wagimin (2001), examined the effect of job motivation on performance, stating job motivation is closely related to work behavior and performance. The theory of motivation theory of Herzberg's two factors and the process theory of the Porter \& Lowler model (Robbin \& Judge, 2017; Pant \& Yadav, 2016), suggest that there are a number of factors that can motivate and their relation to performance. Research conducted by (Dobre 2013; Nduka, 2016; and Shikar et al., 2001), concluded that job motivation has a significant effect on organizational performance. A number of other researchers also stated that leadership style has a significant effect on job motivation (Fickie, 2007; and Runi et al., 2017). Furthermore, leaders with leadership styles that are appropriate to the needs of the organization can have an impact on increasing organizational performance (Borrill $e t$ al., 2005; Waldman et al., 2005). Based on these, the following research hypothesis is proposed.

Hypothesis 3: Job motivation has a significant effect on LPD performance.

Hypothesis 4: Job motivation mediates the influence of leadership style on LPD performance.

\section{Materials and Methods}

The study population was all Village Credit Institutions (LPD) in the City of Denpasar, Bali. The number of LPD in Denpasar City is 35 LPDs spread over four sub-districts. Based on the LPD health assessment, there were three LPDs declared unhealthy so that the study population became 32 LPD. Determination of the sample using the proportional random sampling method of the entire target population of 32 LPD with a total of 477 employees. Furthermore, the minimum sample is determined based on 10 times the number of research indicators, namely 9 indicators so that the minimum sample is 90 employees. However, in anticipation of invalid answers, the number of employee samples taken was 115. Questionnaires were given to respondents containing questions about leadership style referring to Fidler (1981), job motivation refers to Herzberg's theory (Robbins \& Judge, 2017), and LPD performance adopts organizational performance measurements (Kaplan \& Norton, 1997). Before the questionnaire was distributed as a whole, the questionnaire was tested using validity tests $(r>0.30)$ and reliability (Cronbach alpha> $0.60)$ and was declared valid and reliable. Furthermore, the data collected was analyzed using SmartPLS inferential analysis. The results of distributing questionnaires obtained as many as 100 valid questionnaires, illustrated in the profile of respondents, below.

Table 1

Respondent profile information

\begin{tabular}{|c|c|c|c|}
\hline No & Description & Quantity & Percentage \\
\hline \multirow[t]{4}{*}{1} & Gender & & \\
\hline & - Male & 30 & 30.0 \\
\hline & - Female & 70 & 70.0 \\
\hline & Total & 100 & 100,0 \\
\hline \multirow[t]{5}{*}{2} & Ages & & \\
\hline & - $\quad 20$ - 29 years old & 1 & 1,00 \\
\hline & - $\quad 30$ - 39 years old & 14 & 14,00 \\
\hline & - 40 - 49 years old & 56 & 62,00 \\
\hline & - >50 years old & 29 & 21,00 \\
\hline
\end{tabular}




\begin{tabular}{rlll}
\hline No & Description & Quantity & Percentage \\
\hline \multirow{3}{*}{ Total } & 100 & 100,00 \\
& Working Time & 4 & 4,00 \\
& $: \quad 1-9$ years & 40 & 40,00 \\
& $:$ 10 - 19 years & 50 & 50,29 \\
& $:$ 20 - 29 years & 6 & 6,00 \\
& Total 30 years & 100 & 100,0 \\
4 & Education Background & 71 & 71,00 \\
& $:$ Senior High School & 16 & 16,00 \\
& $:$ Diploma & 13 & 13,00 \\
& Total & 100 & 100,0 \\
\hline
\end{tabular}

Primary Data, 2019

\section{Results and Discussions}

\section{Evaluation of Measurement Model (Outer Model)}

Outer model evaluation aims to determine the validity and reliability of indicators that measure latent variables, namely leadership style (X1), job motivation (Y1), and LPD performance (Y2). Evaluation of the measurement model is done by examining composite reliability, convergent and discriminant validity. Composite reliability aims to test the reliability value between the construct indicator blocks that form reflexive indicators. Composite reliability results are said to be good if the value is above 0.70 . Based on the composite coefficient value, the variables that make up the research model have values above 0.70 . This means that all the reflexive indicators that make up the research model are reliable (Table 2). In the PLS analysis also tests the validity of the disk drivers by taking into account the average variance extracted (AVE) value of each construct. If the AVE value is greater than 0.50, it can be concluded that the construct has a good discriminant validity value or vice versa. The test results show the AVE value in the study variable above 0.5 . Thus, it can be concluded that the measurement model has met the requirements of discriminant validity (Table 2).

Table 2

Composite reliability

\begin{tabular}{lll}
\hline Variable & Composite coefficient & Average variance extracted (AVE) \\
\hline Leadership Style & 0,948 & 0,783 \\
Job Motivation & 0,800 & 0,697 \\
LPD Performance & 0,920 & 0,551 \\
\hline
\end{tabular}

Primary Data, 2019

The convergent validity results are shown in the following table below:

Table 3

Convergent validity

\begin{tabular}{lllll}
\hline Variable & $\begin{array}{l}\text { Symbol of } \\
\text { Indicator }\end{array}$ & Outer loading & T - Statistic & \multirow{2}{*}{ Description } \\
\hline Leadership Style & X1.1 & 0.932 & 35.703 & Valid \\
& X1.2 & 0.969 & 67.409 & Valid \\
\multirow{2}{*}{ Job Motivation } & X1.3 & 0.969 & 96.572 & Valid \\
& Y1.2 & 0.824 & 18.628 & Valid \\
LPD Performance & Y1.2 & 0.910 & 67.504 & Valid \\
\hline
\end{tabular}

Mantera P., I. B. S., \& Riana, I. G. (2019). Predicting business performance through leadership style and job motivation. International Research Journal of Management, IT and Social Sciences, 6(5), 184-192. https://doi.org/10.21744/irjmis.v6n5.724 


\begin{tabular}{lllll}
\hline Variable & $\begin{array}{l}\text { Symbol of } \\
\text { Indicator }\end{array}$ & Outer loading & T - Statistic & Description \\
\hline & Y2.2 & 0.919 & 46.944 & Valid \\
Y2.3 & 0.889 & 14.120 & Valid \\
Y2.4 & 0.888 & 24.258 & Valid \\
\hline
\end{tabular}

Primary Data, 2019

The test results show that all construct loading indicator outer values in the research model have values above 0.5 so that it can be concluded that the measurement of the model has met the convergent validity requirements.

\section{Goodness of Fit Model}

Goodness of Fit (GoF) testing of structural models in the inner model uses the predictive-relevance $\mathrm{Q}^{2}$ value to test the prediction of the model, namely endogenous $\mathrm{R}$-square variables. Predictive-relevance $\left(\mathrm{Q}^{2}\right)$ can be used to determine the effect of exogenous variables on endogenous variables in the model. $\mathrm{R}^{2}$ values for each endogenous variable in this study can be seen in the following Table 4.

Table 4

$\mathrm{R}^{2}$ testing result

\begin{tabular}{ll}
\hline Dependent Variable & $R$-square \\
\hline Job Motivation & 0.561 \\
LPD Performance & 0,633 \\
\hline
\end{tabular}

Primary Data, 2018

The predictive-relevance $\mathrm{Q}^{2}$ value is obtained by the formula below:

$$
\begin{aligned}
& \mathrm{Q}^{2}=1-\left(1-\mathrm{R}_{1}^{2}\right)\left(1-\mathrm{R}_{2}^{2}\right)=>\mathrm{Q}^{2}=1-(1-0,561)(1-0,633) \\
& \Rightarrow \mathrm{Q}^{2}=1-(0,439)(0,367) \\
& \mathrm{Q} 2=1-0,161 \Rightarrow \mathbf{Q}^{2}=\mathbf{0 , 8 3 9}
\end{aligned}
$$

The calculation results show that the predictive-relevance value is $0.839(>0)$ which means that the model meets the predictive criteria well. It can also be explained that $83.9 \%$ of the variation in LPD performance variables can be explained by the variables used in the research model namely leadership style and job motivation. While the remaining $16.1 \%$ of the research model is explained by other variables not used in the research model.

Table 5

Hypothesis Testing Result

\begin{tabular}{|l|l|l|l|l|}
\hline Variable Correlation & $\begin{array}{l}\text { Path } \\
\text { coefficient }\end{array}$ & $\begin{array}{l}\text { Mean of } \\
\text { subsamples }\end{array}$ & T-Statistic & Description \\
\hline Leadership style $\rightarrow$ LPD performance & 0.465 & 0.414 & 3.704 & Significant \\
\hline Leadership style $\rightarrow$ job motivation & 0.795 & 0.781 & 9,492 & Significant \\
\hline Job motivation $\rightarrow$ LPD performance & 0.324 & 0.375 & 2.214 & Significant \\
\hline
\end{tabular}

Primary Data, 2019

Table 5 informs hypothesis 1 (H1), that the leadership style has a positive and significant effect on LPD performance received with a path coefficient of 0.465 and t-statistics of $3.704(>1.96)$. Furthermore, hypothesis 2 (H2) that leadership style has a significant positive effect on job motivation is accepted with a path coefficient of 0.795 and $t-$ statistic of 9,492 (> 1.96). Furthermore, hypothesis $3(\mathrm{H} 3)$ that motivation has a positive and significant effect on LPD performance can be accepted with a path coefficient of 0.324 and t-statistics of 2.214 (> 1.96). While Hypothesis 4 (H4), the result of job motivation partially mediates the influence of leadership style on LPD performance (Hair et al., 2010). 
Discussion and Implications

Leadership is a way carried out by a leader to direct and encourage subordinates to achieve their desires so as to produce maximum performance (Yukl, 2010). Therefore, a leader is required to be able to interact with subordinates in the organization. An evaluation of the success of effective leadership can be seen from how well the performance resulted in carrying out the organization's vision and mission. Tatulus et al., (2015), said that a leadership model that is tailored to the needs of the organization and carried out with full responsibility can reduce various problems that hamper the performance of employees and businesses. In addition, the accuracy of the leader interaction style with subordinates is also seen as being able to improve business performance (Borrill et al., 2005; Waldman et al., 2005; and Ogbonna \& Lioyd, 2000).

Leadership is a person able to influence followers, both directly and indirectly while providing motivation to followers to achieve common goals (Thoha, 2013). The success of an organization in motivating employees is very dependent on the success of the leader in managing human resources owned, able to give an appreciation of the success of employees, and have a friendly nature to each employee. Kabacoff (2002), has tested the truth of Herzberg's theory that a high degree of conformity between personal motivation (working to get emotional results) and leadership style (specific leadership behavior patterns) has the potential to improve performance. The leadership style is significantly able to encourage employee job motivation (Suseno et al., 2010) so that it contributes positively to the organization (Hanafiah et al., 2014). A number of research results also reveal that leadership style has a direct impact on job motivation (Siregar et al., 2016; Ali \& Meshal, 2016; and Runi et al., 2017).

Furthermore, Gibson et al., (1996) and Fickie (2007), stated job motivation is closely related to work behavior and performance. Herzberg's two-factor theory (Robbins \& Judge, 2017), reveals a number of factors that can move a person and their relationship to performance. There are two factors that encourage employees to be motivated to work, namely intrinsic factors that arise from within themselves, and extrinsic factors that are more to the force of outside self tend to see what is given. Research conducted by Gani (2006); Wagimin (2001); Shikar et al., (2001), concluded that job motivation affects organizational performance. This means that employees who have strong motivation tend to contribute optimally to the organization.

The analysis also shows that job motivation partially mediates the influence of leadership style on LPD performance. This shows that directly the leadership style has a significant effect on LPD performance (Ali \& Meshal, 2016; Fickie \& Rawung, 2007; and Runi et al., 2017). Whereas, leadership style indirectly influences LPD performance through job motivation (Shikar et al., 2001: Masi \& Robert, 2000). This indicates that the leader has an important role in increasing job motivation and employee performance so that it impacts on organizational performance.

The leadership style that suits the needs of the organization can improve LPD performance (Waldman et al., 2005; and Ogbonna \& Lioyd, 2000). Similarly, leaders who are able to interact with subordinates can motivate subordinates to work (Barbuto \& John, 2005; Amjad et al., 2016), so as to make a maximum contribution to the organization (Hanafiah et al., 2014). In other words, leaders who always pay attention to the task structure are able to move the employee's desire to perform better (Ali \& Meshal, 2016) and always try to maximize their contribution to the organization.

The results of this study cannot be generalized to other LPDs because the problems faced by each LPD are different. In addition, perceptual studies using cross-section data often experience changes in perception of the indicators used so that this study can only be used to predict the influence of variables on the model when this research is conducted. Based on the predictive relevance value of 0.839 , it can be interpreted that the model is still possible to be re-tested using other variables outside the model that can affect LPD performance. Therefore, future research is still possible to use other determinants that can affect LPD performance.

\section{Conclusion}

Various things can be done by a leader to bring the organization to the gate of success. Contingency theory or models (Fiedler, 1995) often called situational theory suggests leadership depends on the situation. Fiedler's contingency model sees the effectiveness of groups depending on the match between the style of the leader is interacting with subordinates. Leadership does not occur in one social vacuum so leaders try to influence group members in specific situations. The leadership style adopted by a leader can improve business performance. In other words, leaders who are able to develop a friendly nature and give rewards to subordinates who excel can improve business performance. In addition, leaders who work with clear task structures, build good relationships with employees, and position employees according to their fields have an impact on increasing employee job motivation.

Mantera P., I. B. S., \& Riana, I. G. (2019). Predicting business performance through leadership style and job motivation. International Research Journal of Management, IT and Social Sciences, 6(5), 184-192. 
Motivation is an impulse that directs oneself to behave in actions to achieve the desired goals. Furthermore, employees who have high job motivation tend to strive to make optimal contributions to the organization. However, job motivation does not fully help in improving business performance without leadership style support. Therefore, leadership style plays an important role to increase motivation by providing a clear task structure to employees so that employees can make a positive contribution to business performance.

\section{Conflict of interest statement}

The authors declared that they have no competing interest.

\section{Statement of authorship}

The authors have a responsibility for the conception and design of the study. The authors have approved the final article.

\section{Acknowledgments}

The authors would like to thank the editor of IRJMIS for their valuable time, support, and advice in completing the present research. 


\section{References}

Alghazo, A. M., \& Al-Anazi, M. (2016). The Impact of Leadership Style on Employee's Motivation. International Journal of Economics and Business Administration, 2(5), 37-44.

Ali, A., Bin, L. Z., Piang, H. J., \& Ali, Z. (2016). The impact of motivation on the employee performance and job satisfaction in it park (software house) sector of Peshawar, Pakistan. International Journal of Academic Research in Business and Social Sciences, 6(9), 297-310.

Barbuto Jr, J. E. (2005). Motivation and transactional, charismatic, and transformational leadership: A test of antecedents. Journal of Leadership \& $\quad$ Organizational Studies, $11(4), \quad 26-40$. https://doi.org/10.1177\%2F107179190501100403

Bernardin, H. J., \& Villanova, P. (2005). Research streams in rater self-efficacy. Group \& Organization Management, 30(1), 61-88.

Borrill, C., West, M. A., \& Dawson, J. (2005). The relationship between leadership and trust performance. Aston Business School.

Buford Jr, J. A., Bedeian, A. G., \& Lindner, J. R. (1995). Management in Extension Ohio State University Extension, Columbus, Ohio.

Cole, S. A., \& Shastry, G. K. (2009). Smart money: The effect of education, cognitive ability, and financial literacy on financial market participation (pp. 09-071). Boston, MA: Harvard Business School.

Dobre, O. I. (2013). Employee motivation and organizational performance. Review of applied socio-economic research, 5(1).

Eskildsen, J., Westlund, A. H., \& Kristensen, K. (2003). The predictive power of intangibles. Measuring Business Excellence, 7(2), 46-54.

Fickie, K., \& Ortwein, M. (2007). U.S. Patent Application No. 11/542,416.

Fiedler, F. E. (1995). Cognitive resources and leadership performance. Applied Psychology, 44(1), 5-28. https://doi.org/10.1111/j.1464-0597.1995.tb01378.x

Gani, L., \& Jermias, J. (2006). Investigating the effect of board independence on performance across different strategies. The International Journal of Accounting, 41(3), 295-314. https://doi.org/10.1016/j.intacc.2006.07.009

Gibson, J. L., Ivancevich, J. M., \& Donnelly, J. H. (1996). Organisasi: Perilaku, Struktur dan Proses. Bina Rupa Aksara. Jakarta.

Hair, J. F., Black, W. C., Babin, B. J., Anderson, R. E., \& Tatham, R. L. (2010). Multivariate Data Analysis, [Google Scholar].

Hanifah, H., Susanthi, N. I., \& Setiawan, A. (2014). The Effect of Leadership Style on Motivation to Improve the Employee Performance. Jurnal Manajemen Transportasi \& Logistik, 1(3), 221-226. http://dx.doi.org/10.25292/j.mtl.v1i3.20

Hellriegel, D., \& Slocum, J. W. (2011). Organizational Behavior (wydanie 13). Belmont, CA: Cengage South-Western.

Heyrani, A., Maleki, M., Marnani, A. B., Ravaghi, H., Sedaghat, M., Jabbari, M., ... \& Abdi, Z. (2012). Clinical governance implementation in a selected teaching emergency department: a systems approach. Implementation science, $7(1), 84$.

Hidayat, R., \& Budiatma, J. (2018). Education and job training on employee performance. International Journal of Social Sciences and Humanities, 2(1), 171-181. https://doi.org/10.29332/ijssh.v2n1.140

Ivancevich, J. M. (2005). Administración de recursos humanos. McGraw-Hill Interamericana.

Ivancevich, J. M., Matteson, M. T., \& Konopaske, R. (1990). Organizational behavior and management.

Judge, T. A., \& Robbins, S. P. (2017). Essentials of organizational behavior. Pearson Education (us).

Kabacoff, R. I. (2002). Leadership: What has age got to do with it. Research release. New York: Management Research Group.

Kaplan, R. S., \& Norton, D. P. (2001). Transforming the balanced scorecard from performance measurement to strategic management: Part I. Accounting horizons, 15(1), 87-104. https://doi.org/10.2308/acch.2001.15.1.87

Lembaga Pemberdayaan Lembaga Perkreditan Desa Kabupaten/Kota (LPLPDK). (2011).

Lembaga Pemberdayaan Lembaga Perkreditan Desa Provinsi (LPLPDP). (2018).

Li, F. (1999). The exercise motivation scale: Its multifaceted structure and construct validity. Journal of applied sport psychology, 11(1), 97-115. https://doi.org/10.1080/10413209908402953

Luthans, F. (2006). Perilaku Organisasi,(Alih Bahasa VA Yuwono, dkk). Edisi Bahasa Indonesia, Yogyakarta: ANDI.

Mardika, I. N. (2017). Opposition of community citizenship against the policy of the village's leader. International Journal of Social Sciences and Humanities, 1(3), 74-87. https://doi.org/10.29332/ijssh.v1n3.57

Mantera P., I. B. S., \& Riana, I. G. (2019). Predicting business performance through leadership style and job motivation. International Research Journal of Management, IT and Social Sciences, 6(5), 184-192. https://doi.org/10.21744/irjmis.v6n5.724 
Martini, L. K. B., Suardana, I. B. R., \& Astawa, I. N. D. (2018). Dimension Effect of Tangibles, Reliability, Responsiveness, Assurance, Empathy, Leadership towards Employee Satisfaction. International Research Journal of Management, IT and Social Sciences, 5(2), 210-215.

Masi, R. J., \& Cooke, R. A. (2000). Effects of transformational leadership on subordinate motivation, empowering norms, and organizational productivity. The International Journal of Organizational Analysis, 8(1), 16-47. https://doi.org/10.1108/eb028909

Mitchell, G. (1992). The campaign of the century: Upton Sinclair's race for governor of California and the birth of media politics. New York: Random House.

Obiekwe, N. (2016). Employee motivation and performance.

Ogbonna, E., \& Harris, L. C. (2000). Leadership style, organizational culture and performance: empirical evidence from UK companies. International Journal of Human Resource Management, 11(4), 766-788. https://doi.org/10.1080/09585190050075114

Pant, I., \& Yadav, R. K. (2016). Impact of emotional intelligence on the job performance of employee. International Research Journal of Management, IT and Social Sciences, 3(1), 7-14.

Paracha, M. U., Qamar, A., Mirza, A., Hassan, I. U., \& Waqas, H. (2012). Impact of leadership style (transformational $\&$ transactional leadership) on employee performance $\&$ mediating role of job satisfaction. Study of private school (educator) in Pakistan. Global Journal of Management and Business Research, 12(4), 55-64.

Rawung, F. H. (2013). The effect of leadership on the work motivation of higher education administration employees (Study at Manado State University). Journal of Business and Management, 15(1), 28-33.

Riana, I. G. (2015). Effects Motivation on Business Performance: The Mediation Role of Job Satisfaction and Leadership (A Study in Village Credit Institutions). European Journal of Business, Economics and Accountancy, 3(2).

Runi, I., Ramli, M., Nujum, S., \& Kalla, R. (2017). Influence Leadership, Motivation, Competence, Commitment To Satisfaction And Performance Lecturer At Private Higher Education Kopertis Region IX In South Sulawesi Province. Journal of Business and Management (IOSRJBM), 19(7), 56-67.

Ryan, R. M., \& Deci, E. L. (2000). Self-determination theory and the facilitation of intrinsic motivation, social development, and well-being. American psychologist, 55(1), 68.

Sari, I. G. A. D. I., \& Dwirandra, A. (2019). The ability of organization commitment and moderate worked motivation by the effect of budget goal clarity in budgetary inaccuracy. International Research Journal of Management, IT and Social Sciences, 6(3), 11-17. https://doi.org/10.21744/irjmis.v6n3.622

Sarin, S., \& Mahajan, V. (2001). The effect of reward structures on the performance of cross-functional product development teams. Journal of marketing, 65(2), 35-53. https://doi.org/10.1509\%2Fjmkg.65.2.35.18252

Siregar, R., \& Widyawati, D. (2016). Pengaruh karakteristik perusahaan terhadap penghindaran pajak pada perusahaan manufaktur di BEI. Jurnal Ilmu dan Riset Akuntansi, 5(2), 2460-0585.

Suseno, M. N. M. (2010). Pengaruh Dukungan Sosial dan Kepemimpinan Transformasional Terhadap Komitmen Organisasi dengan Mediator Motivasi Kerja. Jurnal Psikologi, 37(1), 94-109.

Tatulus, A., Mandey, J., \& Rares, J. (2015). Pengaruh Kepemimpinan Terhadap Kinerja Pegawai Negeri Sipil di Kantor Kecamatan Tagulandang Kabupaten Sitaro. Jurnal Administrasi Publik, 2(30).

Thoha, M. (2013). kepemimpinan dalam manajemen, edisi 1. Jakarta, PT RajaGrafindo.

Tylana, X. E. (2006). The Impact of Motivation on Job Satisfaction amongs Employeess of a National Broadcaster, Magister Commerchii, Bussiness Management, University of Johanesberg.

Van Herpen, M., Van Praag, M., \& Cools, K. (2005). The effects of performance measurement and compensation on motivation: An empirical study. De Economist, 153(3), 303-329.

Veithzal Rivai, E. J. S. (2014). Manajemen Sumber Daya Manusia untuk Perusahaan: Dari Teori ke Praktik. Rajawali Pers.

Wagimin, I. (2001). Pengaruh Motivasi dan Kemampuan Terhadap Prestas Kerja (Doctoral dissertation, Tesis. Malang: Universitas Brawijaya).

Waldman, A. D., Ramirez, G. G., Hause, R. J., \& Puraman, P. (2005). DoesLeadership Matters.

Yukl, G. (2010). Kepemimpinan dalam organisasi. Jakarta: PT Indeks. 